\title{
Vasa vasorum
}

铇田克彦* 鈴木 敏 己**

\section{はじめに}

Vasa vasorum は血管壁栄養血管と訳されて いるが，血管壁の栄養供給にあずかるとの考か ら Vasa nutria とも呼ばれる。Vasa vasorum の 存在については 1621〜1675 年に大動脈の Vasa vasorum が発見されたのに始まり，Vasa vasorum の分布, Vasa vasorum の出所する動脈, Vasa vasorum の流入する静脈，色素または墨 汁注入標本の検討など解剖学的研究が進められ てきたが，1960年頃より microangiography が この領野にも導入され，特に Clarke, J.A.1 6) によって胎児より成人に至る各種動脈の Vasa vasorum の分布, 発生, 消失時期などにつき詳 細な検索がなされるに至った。

しかしかかる形態学的研究の進歩にもかかわ らず，方法論の困難さもあって Vasa vasorum の生理, 薬理はほとんど検討されていない。僅 かに動物の Vasa vasorum を実験的に傷害し, これの分布する血管壁の変化を追究することに より, 人に見られる血管病変の発生病理の理解 を助けよらとの試みがなされている。私共7) も 犬の腹部大動脈壁の栄養血管を傷害する方法を 案出し, 剥離性大動脈瘤の原因になる 囊胞性 中膜壊死の像ともいえる所見を得，また高 cholesterol 血作製に上記 Vasa vasorum 傷害手 術を加味することにより, 粥状硬化の初期像と

* 東北大学医学部第一内科

** 秋田県立脳血管研究センター
もいえる所見を得ることができた8)。

\section{Vasa vasorum の形態学的観察}

\section{Vasa vasorum を有する血管}

胎児大動脈では $0.8 \mathrm{~mm}$ の口径になって始め て Vasa vasorum が出現するといわれ ${ }^{9)}$, 成 人では直径 $1.0 \sim 1.2 \mathrm{~mm}$ 以上の動脈壁と $1.0 \sim$ $1.5 \mathrm{~mm}$ 以上の静脈壁に Vasa vasorum が認め られるといわれる10)。下腿動・静脈を検索した 報告によると，動脈ではその壁が少なくとも $300 \mu$ あれば Vasa vasorum が見られるが，静

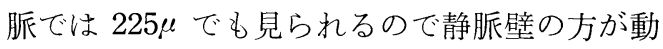
脈壁よりも貪欲であるといら。一方脳動脈では 前・中大脳動脈と Willis 環の大部分, および 後大脳動脈はV Vasa vasorum を有しないこと が Clarke ${ }^{5)}$ により明らかにされ，この面より も脳内動脈が他の動脈之違った性質を有するこ とが伺われる。

\section{2. 栄養動脈の出所する動脈}

Vasa vasorum は一般に附近の小動脈の分枝 から扣こって外膜側から血管壁内に分布する が，血管内腔から直接起始して血管壁内に分布 するもの，または血管内腔からおこって血管壁 内に分枝を出し，さらに血管外に出て再び血管 壁内に外膜側から分布するものも見られる。

な颃外膜側から血管壁内に侵入する栄養動脈 は胎生期その血管が Vasa vasorum を必要とす る大きさに達した時期に至近の動脈枝から栄養 動脈を受けるが，成長するにつれて血管相互の 


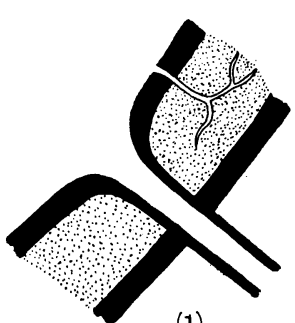

(1)

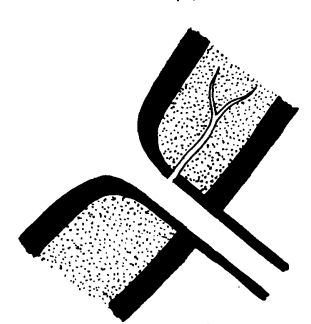

(3)

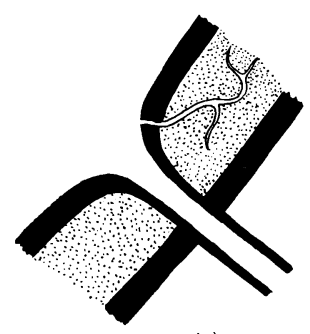

(2)

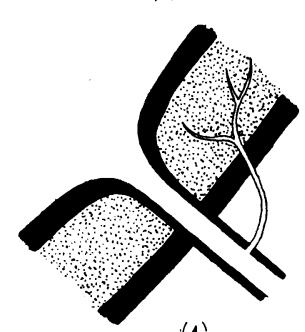

(4)
図 1 大動脈に括ける Vasa vasorum 直接技 (1), 招上びその発生に伴う移動。(1) $\rightarrow$ $(2) \rightarrow(3) \rightarrow(4)$ 塚本 $\left.{ }^{9}\right)$ 上り引用。

位置的関係が変わり, 例えば成人の胸部大動脈 が遠く甲状腺動脈から分枝を受けているよう に9)，循環障害を沶こしやすい一因になるか子 知れない。

血管内腔から直接出る栄養動脈については, 多くの研究があるが, 著者らも microangiography と India ink 注入法によって犬大動脈にか かる直接枝の存在を確認し, その頻度としては 上行大動脈に多く認められたが，血管外側から 分布しているVasa vasorumに比べれば少なか った。血管内腔から出て中膜に分布し外膜に分 布しない栄養動脈は特に Vasa vasorum interna とも呼ばれるが, 著者らの成績ではこの種のも のは比較的少なく, 血管内腔から出て中膜に分 枝を出し, さらに外膜にも分枝を出し, それか ら血管外方に一度出てから再び外膜に分布する ものが多かった。

かかる直接枝は人体では胎児の大動脈に比較 的多く見られるが成人の大動脈では見られない か, あるいは存在しても多くはない。その理由 として塚本 ${ }^{9)}$ は, 図 1 亿示すように胎览大動
脈における直接栄養動脈は大動脈の太くなるの に伴って次第にその起始部を大動脈分枝に移動 するためであるとしている。その他の動脈とし て, 冠動脈や四肢動脈にしばしば内腔からの直 接栄養動脈が認められている10)。

\section{3. 栄養静脈の流入する静脈}

血管壁内で毛細血管の血液を集めた栄養静脈 が血管壁を出てどの静脈に流入するかについて も，2，3の報告があるが,、一般に栄養動脈の 数よりも栄養静脈の数は遙かに少ないようであ る9)。また栄養動脈における直接枝のごとく, 静脈の栄養静脈が直接その静脈に流入するよう なものはあまり見られず, 下大静脈に僅かに認 められている10)。

\section{Vasa vasorum の分布とその境界}

\section{a) 大動脈}

microangiography によると大動脈壁の外膜に は樹枝状に分布し，さらに互いに吻合し合って いる豊富な血管叢が見られると共に外膜程では ないが中膜にも同様な血管が認められる。須永 ら11)の犬の大動脈の研究によると大動脈の後 面では明らかに前面より分布密度が大であっ た。Vasa vasorum の走行は大動脈壁の横断面 を走るものと縦断面を走るものが見られ，血管 壁に対し縦横に分布しているのがみられる。

Vasa vasorum の分布の境界については中 膜の外 $1 / 3$, 中膜の外 $1 / 2^{10)}$, 中膜の中 $1 / 3$ お よび 中膜全層1)と種々なる意見があるが，私 共の実験ではVasa vasorum は外膜と中膜の 中 $1 / 3$ まで分布していた。中膜全層とする Clarke1) は栄養動脈枝は中膜の中 $1 / 3$ までに みられ, 中膜の内 $1 / 3$ には毛細血管と栄養静 脈がみられ，ここで動静脈吻合も見られると述 べ，須永ら ${ }^{11)}$ 同様な所見を得たと報告して いる。しかし Clarke は他の大部分の報告者と 同様内膜における Vasa vasorum の存在を否定 している。

動脈硬化のない正常大動脈の内膜にVasa vasorum が分布しているといら報告は馬, 牛 の大動脈，ならびに須永ら 


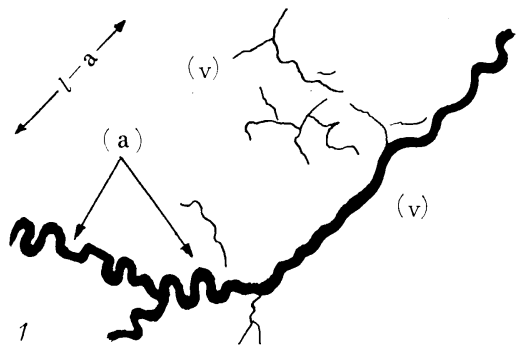

図 2 人鎖骨下動脈外膜（v）内に打子る arteriole (a)。コイル状蛇行を見 る。 Clarke ${ }^{2)}$ ょり引用。

ける報告があるのみである。

Vasa vasorum 分布の境界には年歯 的因子が大きく関与し，塚本 ${ }^{9}$ による

と, 胎児に始めて大動脈 Vasa vasorum がみ られる時期には外膜内に限られるが，胎生 5 力 月において中膜外層に達し, 7 力月以後には中 膜の半ばに達するといわれ, Clarke ${ }^{3)}$ は 4 歳児 では中膜の外 $1 / 3$ まで，10歳児では中膜の $2 / 3$ までに分布し, 13 歳では栄養静脈が 中膜の内 1/3にみられるようになると述べている。

b ) 肺動脈

栄養動脈は外膜と中膜の外 $1 / 3$ まで分布し, 栄養静脈は中膜の中 $1 / 3$ から抏こり, 外膜を通 って血管外に出ている。中膜の中 $1 / 3$ に動静脈 吻合がみられる。肺動脈においては中膜の内 $1 / 3$ と内膜には Vasa vasorum は存在しな $(4)$ 。

c ）筋性動脈

Clarke ${ }^{2) 12)}$ は人の冠動脈や四肢動脈（大腿 動脈, 腋窩動脈などの比較的太い動脈) では栄 養動脈は外膜と中膜の外 $1 / 3$ にみられ, 栄養静 脈は中膜の中 $1 / 3$ のところから抗こり，ここで 動静脈吻合がみられ, さらに外膜にみられる Vasa vasorum は図 2 に示すよらにコイル状に 蛇行していて，血管の伸展に適応するような構 造を示していると述べている。四肢動脈のより 細い所では Vasa vasorum は外膜にの久認めら れるといら。

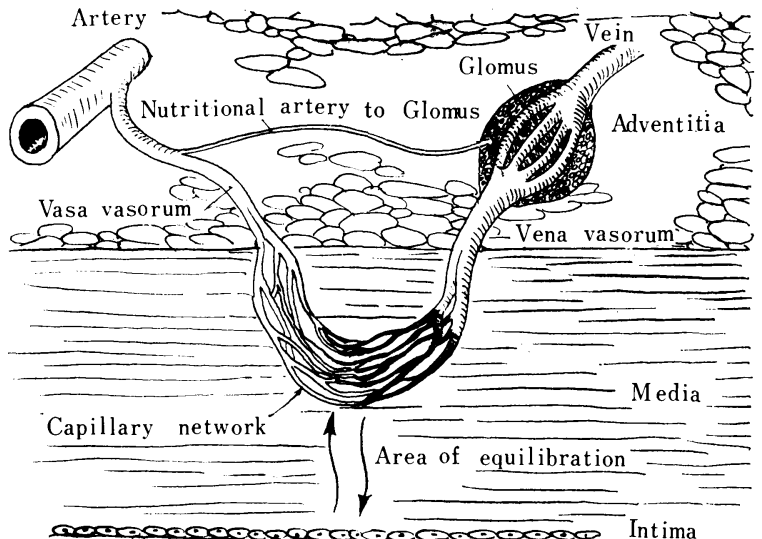

図 3 猫の aorticopulmonary glomus tissue と血管との 関係。 Hughes ${ }^{13)}$ より引用。

\section{d）静脈 系}

静脈壁に拉ける Vasa vasorum についての報 告は少なく，その分布についても内膜近く迄と するもの，外膜・中膜までとするものなど意見 の一致を見ていない。しかし一般に静脈壁の Vasa vasorum は外膜において血管の縦断面に 平行に走る傾向があり,この点は動脈壁におけ る走行と異なっている。

\section{Vasa vasorum を繞る話題}

\section{1. glomus tissue と Vasa vasorum}

頸動脈洞や大動脈弓部には carotid body, aortic body と呼ばれる特種な細胞集団から成 る器官があり, 豊富な神経叢を有し, glomus tissue なる名前で総称され, 生理学的には化学 受容体 (chemoreceptor), 圧受容体 (baroreceptor）と考えられている。

1965年 Hughes ${ }^{23)}$ は図 3 に示したようにネコ の肺動脈壁にある glomus tissue と Vasa vasorum について興味深い関係を見出した。肺動脈 壁の中膜の外半分の部分にある毛細管網から出 る Vasa vasorum が外膜と中膜の境に存在する glomus tissue の中に入って毛細血管となり, 再 び静脈となって上大静脈, または冠状静脈洞に 入り, 結局毛細血管網を二度経過する点は丁度 門脈系の構造に類似する。さらに肝における肝 


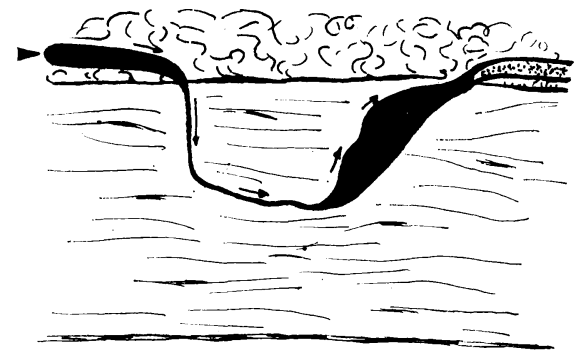

DIASTOLE

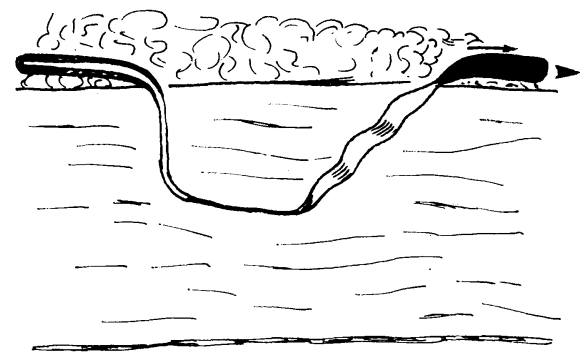

SYSTOLE

図 4 圧受容体域に打ける sinus の機能を説 明する模式図。収縮期に空となり拡張期に充

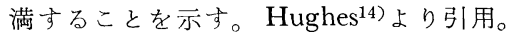

動脈に相当する動脈が glomus tissue に分布し ていることを認めた。このような構造を有する Vasa vasorum は大動哌弓の前, 後の glomus tissue にも見出されている。この glomus tissue に 直接分布している栄養動脈は拈そらく glomus tissue に酸素を供給する役割を有し，この Vasa vasorum の門脈系様の構造は glomus cell に血液ガスの変動ヤ血液量の変化を伝達し, 心 血管系の調節に関与しているものと推測され る。

その後 Hughes ${ }^{14)}$ は猫と犬の頸動脈洞と大動 脈壁の baroreceptor と Vasa vasorum との関係 について検索し, baroreceptor としての作用を 有する領域の glomus tissue では図 4 亿示すご とく栄養動脈系より栄養静脈系の占める割合が 大で, 栄養静脈系は心拍動の拡張期に膨張して 血流が急速に満たされ, 収縮期には急速に血液 が血管外に駆出されて栄養静脈系内には血液が 空になる “venous pump”としての機構を有 し, 栄養静脈系の急速な拡張と収縮による周囲

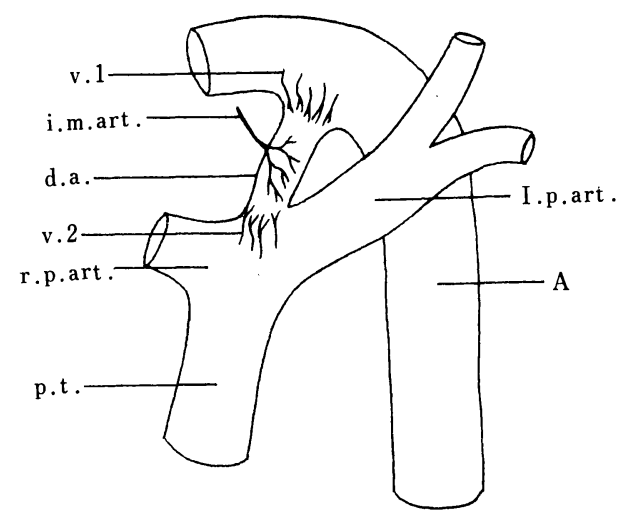

図 5 ボタロ一氏管に分布する栄湌動脈。 d.a.：ボタロ一氏管, A: 大動脈, p.t.：肺動脈 幹, r.p. art.: 右肺動脈, 1.p. art.: 左肺動脈, i.m. art.: 内乳動脈, v. 1: 胸部大動脈外膜に拉 ける血管の分技, v. 2: 左肺動脈外膜に扣ける血 管の分技。Clarke ${ }^{6)}$ より引用。

組織への圧変動がその部にある baroreceptor に 伝達されることによって循環調節が行なわれる ものと推測される。

その後寉田 ${ }^{15)}$ はオットセイの頸動派分岐部 附近のVasa vasorum と神経組織との関係を追 究し, 頸動脈の外膜を走る小さな Vasa vasorum はきわめて繊細な神経線維の網で包繞され，こ の神経網は Vasa vasorum が中膜内に入ると消 失する,さらに頸動脈分岐部にある glomus caroticum は組織学的には Hughes ${ }^{13)} の い ら$ glomus tissue と類似の構造を示し, この Vasa vasorum の主な役割は大血管の $\mathrm{O}_{2}$ 需要に即応 して中膜内の局所的血液循環を神経系によって 調節しながら血管壁に十分な酸素を供給するこ とにあるといら。

かかるVasa vasorumを繞る神経系に何らか の変調がおこれば大血管壁の壁内血液循環の調 節機構が失われ，いろいろな病変へと発展する 可能性がある。Rüsager は頸動脈洞の神経終 末の変性を観察し, このような変化はVasa vasorum の閉塞によると述べている。

\section{2. ボタロー氏管の 閉塞機序と Vasa vasorum}


従来ボタロー氏管の閉塞機序として，1）ボ タロー氏管と関係のある臓器が生後偏位を抏こ す結果，ボタロー氏管を索引したり，圧迫した りして内腔を変化させるため，2）既存の㱀譬 が循環動態の変動による圧力を受けるため内腔 が圧迫されて閉塞する，3）出産前に生ずる内 膜の増殖によって内腔の狭窄をおこす，4）括 約筋様の中膜筋層の収縮によって血流が阻害さ れる，の4つの説があげられているが16)，近 年ボタロー氏管の Vasa vasorum の発生, 分 布, 消失時期などについての報告がみられるよ らになり，ボタロー氏管の閉塞機序と Vasa vasorum との関係が論ぜられるようになった。

ボタロー氏管の Vasa vasorumの出現時期は胎 生28週で, 内乳動脈から分枝した直径 10 40 の不規則な血管叢が外膜に出現し，第34週に胸 部大動脈と肺動脈から分枝した直径40～50 $\mu$ の 血管叢がみられるようになり，これらのV Vasa vasorum は生後 1 週の終りから次第に増加し, 第 3 週で最も発達する（図 5 )。この栄養動脈 の出所動脈については上述の大動脈分枝之肺動 脈分枝であるが，気管支動脈枝が主で，栄養静 脈の流入する静脈は半奇静脈之されている。分 布について新生児では外膜にのみ存在するが， 生後 2 力月と 4 力月の乳児では外膜のほか中膜 と内膜にもみられるという。さらに生後年齢が 増加するにつれてボタロー氏管の壁は乏血状態 となるが， Clarke ${ }^{6)}$ は 5 歳児でボタロー氏管の 大動脈側の半分は avascular の状態となり,

1 歳から 80 歳までの 30 例中 3 例の夕に外膜に Vasa vasorum が認められたと述べている。ま た生後ボタロ一氏管に石死化も見られ動脈硬化 の過程と同様な変化が抗こることが指摘されて いる。

一方，ボタロー氏管の閉塞はその血管壁の栄 養障害が前提であると推測され，Harms ${ }^{16)}$ は 生後ボタロー氏管の内膜が大動脈側で強く肥厚 し石灰沈着を生じ, 中膜内 $1 / 2$ 亿壊死巣や出 血の見られることは, 中膜平滑筋の収縮によっ て Vasa vasorum が圧迫されて閉塞する結果生
じた硬塞巣であるとして, ボタロ一氏管閉塞の 機序に Vasa vasorum の変化が関与しているこ とを示唆している。

\section{動脈病変とVasa vasorum}

\section{1. 剝離性動脈瘤と Vasa vasorum}

胸部大動脈に最も多く見られる剥離性動脈瘤 Aneurysma dissecans は動脈壁内，とくにその 中膜内に血液が侵入する状態で, 多くの場合動 脈腔内と交通している。本症には囊胞性中膜 壞死が先行するといわれ，その原因として， Vasa vasorum の変性, 動脈硬化, 狭窄, 中膜 の肥大と内膜の増殖などの変化が大動脈中膜の 栄養障害をおこす結果となって剥離性動脈瘤が 発生するとの考觉が有力である。

また動物のVasa vasorum を実験的に傷害し ておこる血管壁の変化もこれを裏付ける結果と なっている。 Schlichter ら ${ }^{17)}$ は大の大動脈 を，1）パラフィンで包被，2）外膜の除去,

3 ）外膜の焼灼などの方法で Vasa vasorum を 傷害することによって，その部の大動脈中膜の 壊死, 類粘液変性, 線維化, 石灰化, 内膜の増 殖を見，中には囊胞形成，さらに剝離性大動脈 瘤の発生を見たものもあった。

Wilens ら ${ }^{18)}$ は大の胸部大動脈の Vasa vasorum を第 $5 \sim 8$ ，あるいは $4 \sim 7$ の 4 対の肋間 動脈を結禁することによって障害し, 術後 1 ,

2，4，7，14 日間観察して大動脈壁の変化を追 究した。それによれば24時間後水腫と弾性板間 の開離が見られ，4 日後中膜中央部に硬塞像を 認め, 筋細胞の消失が見られた。7日では小量 の膠原線維が見られたが，14日でも壊死部は完 全に治癒してなかった。この実験成績から彼ら は実験犬の大動脈壊死部の所見は人の特 発性 中膜壊死に類似しているので，人においても Vasa vasorum の循環障害が特発性中膜壊死や 剝離性動脈瘤発生に与る重要な因子であろらと 推論している。

以上の実験は外膜を傷害することによって栄 養血管の血流を阻害した訳であるが，条件をさ 
Vasa vasorum 障害部における血行路の回復の経 過を示す Microangiogram

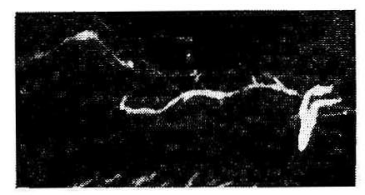

28日間観察犬

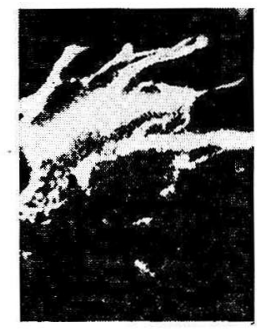

58日間観察犬

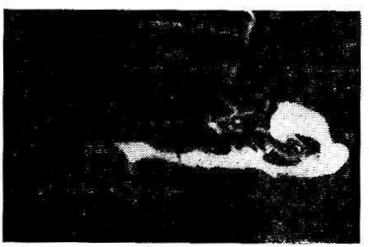

95 日間観察犬

図 6 Vasa vasorum 傷害手術後28日，58日， 95 日後の大の腹部大動脈の microangiogram. 次第に不規則，かつ蛇行した血行の回復が見ら れる。

らに厳密にするため仲田 ${ }^{19)}$ は外膜を傷書する ことなしに, 犬の腰動脈結禁後, 腹部大動脈の Vasa vasorum を選択的に栓塞させて, 動脈壁 の変化を観察した。その結果, 次第に進行する 内膜肥厚, 膠原線維の増殖々中膜の筋細胞や弾 力線維の破壊をみ, $6 \sim 8$ 週例では筋細胞の消 失部に膠原線維の増殖が強く, 壁全周にわたり fibrosis が見られた。

さらに私共は7) 犬の栄養血管を傷害するに 当り, 外側枝のみならず内側枝の血流をも完全 に阻害する目的で下記の方法を案出した。すな わち成犬の下部腹部大動脈を撰びこれに流入す る栄養血管を結禁後大動脈内腔に直径 10 ～150 $\mu$ のアクリル系合成樹脂球の生食懸濁液を注入 し, 術後 2 日から 4 力月間飼育後䖑殺した。術 後 $2 \sim 4$ 日の術部の microangiogram では全く 壁内血行を認めず, 完全な血行遮断に成功した 事が知られたが, 術後 2 週間位より次第に血行 の回復を見，1 カ月ではかなりの程度迄血行路

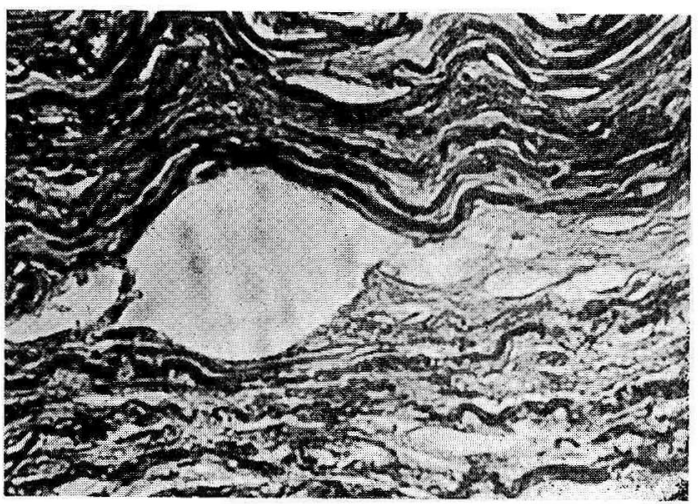

図 7 Vasa vasorum 傷害手術後 1 力月の犬 の腹部大動脈中膜の所見。弾力線維の断裂, 膠原線維の増加と共に整胞様变化多見られ る。

の回復を見たが（図 6)，その血管は壁の不整 な蛇行を伴ったものであった。組織学的検索で は術後 2 日，4 日ではほとんど変化を認めず, その後次第に中膜弾性線維の断裂, 膠原線維の 増殖を見，一部に図 7 に示したごとく囊胞様の 変化も見られた。この変化は次第に高度となり 術後 $3 \sim 4$ 力月では中膜はほとんど膠原線維で 扣さかえられた。中膜の変化と共に内膜に浮 腫, 肥厚, 噖原化を見たが，その变化は術後 1 力月位迄進行し，その後進展を見なかった。こ れらの所見は特発性囊胞性中膜壊死の所見亡多 くの共通点を有し, 剥離性動脈瘤の発生:因子と して Vasa vasorum 傷害による中膜栄埕傷害の 関与を示唆するものと考光られる。

\section{2. 粥状硬化と Vasa vasorum}

Schlichter \& Hariss ${ }^{17)}$ は犬, 人, 鶏, 鬼の上 行大動脈中の血管分布を比較し, この中で最も 栄養血管の分布の多いのは犬で，人はこれに次 ぎ，鶏，鬼の順であるといい，栄養血管の分布 の豊富な動物は分布の少ない動物より変性性動 脈疾患に䍜患しにくいと述べ，人の血管でも肺 動脈や末㮐静脈は Vasa vasorum が豊富で, 動 脈硬化も拈こしにくいことを指摘している。し か乙粥状硬化病変部の人大動脈の栄養血管を組 織学的に検討した Schütte ${ }^{20)}$ の報告では中膜に おける栄養血管の内腔側への増殖は動脈硬化の 
度合とは直接関係なく, 内膜肥厚度と関係あり といい, 大動脈の動派硬化発生に先立って栄養 血管の形態学的変化がおこるとはいえないと述 べているが，動脈瘤の発生についてはその部の 栄養血管の動挀硬化, 血栓形成による硬塞発生 ぶ重要なる役割を演じているといら。

このように動脈硬化の発生に当り Vasa vasorum の血行障害が先行するといら確証がない にかかわらず，動脈硬化の成因を考兵る上で血 管の壁内循環障害を無視することは困難であ る。

Vasa vasorum の分布のところで述べたごと $<$, 正常動脈壁では中膜の内 $1 / 3$ と内膜には Vasa vasorum の分布がなく，脈管内腔から直 接栄養物の浸透により養われている。従って中 膜中層は両者の分水界に当り, 容易に hypoxia をおこしやすい事が知られる。これをきたす因 子として Schlichter \& Harrisi7) は，1）血管 の酸素需要の増大，2）血管壁に対する酸素供 給の減少，の 2 つをあげている。前者には高血 圧，大動脈の生理的成長などが考えられ，後者 には梅毒性大動脈炎, 栄養動脈の狭小化拈よび 漏漫性内膜肥厚なぞをあげることができる。

Adams \& Bayliss ${ }^{21)}$ は各年代の人の各種動脈 について, 内膜肥厚度と中膜における NADH tetrazolium reductase, ATPase の帯状消失との 関係を調べ，一般的に中膜の酵素消失域の拡さ と濔漫性内膜肥厚の拡さとは比例関係にあり, 酵素消失は初め中膜中層に, ついで内層に見出 された。しかし㢬漫性内膜肥厚が, 大動脈につ いては $0.13 \sim 0.17 \mathrm{~mm}$, 他の動脈については $0.2 \sim 0.45 \mathrm{~mm}$ をこえると中膜酵素活性の低下 が見られるといい，この限界值は一般に中膜の 厚さに逆比例した。この結果は進行性濔漫性内 膜肥厚が脈管内腔から中膜への酸素や栄養物浸 透を阻害するといら考を支持するものであり， 中膜における energy 産生の低下は cholesterol の処理に必要な Lipotrophic factor (蛋白や燐 脂質など）の合成を妨げ， cholesterol の壁内沈 着を促し, ひいては動脈硬化へと発展すると考
えている。

当然の推論としてこれと同様の現象をVasa vasorum の実験的血行障害によっても惹起する ことができる。私共7)は前述の方法により栄 養血管傷害手術を行なった後， 2 週間飼育した 犬に ${ }^{3} \mathrm{H}$ で標識した cholesterol を静注し, 72 時間後屠殺して大動哌の各部分に対寸る取り込 みを検討した。その結果, 手術部においては対 照犬に比し標識 cholesterol の取り込又萑を 見，その部では特異活性も高值を示した。さら に subcellular fractionation を行ない, 上清, microsome, mitochondria, nuclear debris 94 画分について検討すると， nuclear debris 画分 への取り込みの増加が見られ，これは細胞外， 線維周囲脂質への取り込みの反映と解釈され た。

さらに 私共 ${ }^{8)}$ はあらかじめ cholesterol, methylthiouracil 投与により高 cholesterol 血を作 製した犬に前記の大動脈栄養血管傷害手術を行 ない，その後 1 力月および 2 力月間引き続き cholesterol, methylthiouracil 飼育を行なった後 屠殺し, 大動脈の变化を観察した。その結果傷 害犬の大動脈は全例 sudan III (図 8), sudan black B（図 9）陽性で, cholesterol 染色（図 10）も半数に陽性を示し, 脂質は主として中膜 の細胞外, 線維周囲に存在し, 一部内膜に見ら れた所もあった。これは手術を行なわず, 同期 間 cholesterol, methylthiouracil 飼育のみを行な った対照犬には見られなかった所見であった。 中島 ${ }^{22)}$ は粥状硬化の初期像として雲絮状肥厚 (cloudy thickening) を強調し，これは内膜の 深層, 内弾性板に近く縦走する弾力線維に沿っ てこれにからみ合らよらな線状の脂質沈着で弾 性線維の老化と関係があるという。私共8)の 実験犬に見られた変化もこれと同様な細胞外, 線維周囲の脂質沈着で, 粥状硬化の初期像とも 思われるが，内弾性板の脆弱性のため内膜より は中膜に脂質沈着を示したものと考㝋ている。

これよりさき, Schlichter ${ }^{17)}$ は 8 頭の犬の大 動脈焼灼手術を行ない, cholesterol + methlyl- 


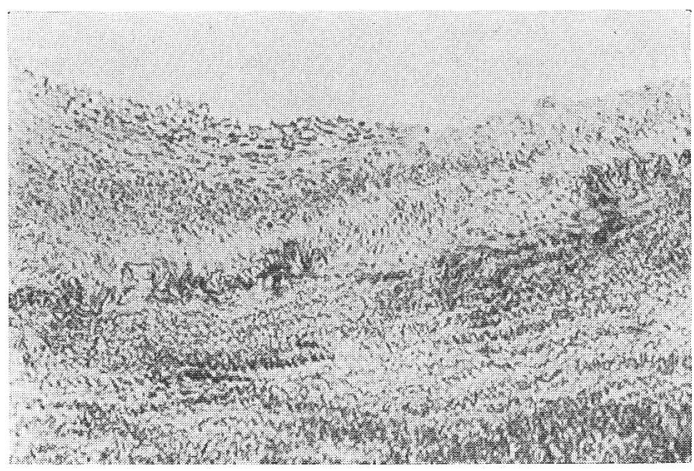

図 8 cholesterol-methylthiouracil 飼育犬の栄養 血管傷害部位の大動脈の sudan black B 染色 標本。100×中膜の線維周用に黒く染る脂質を認 める。一部内膜にも陽性所見あり。

thiouracil 投与を併用して，この中 20 週叔よび 12週飼育犬に atheroma の発生を見ている。

一般的見解としては正常動脈の内膜に Vasa vasorum を認めないが，硬化動脈では内膜にも 小血管を認めるといら報告が多く，これは必 ずしも動脈硬化の程度とは関係せず，一般に 潰愓形成のものに多く見られる。しかして硬 化動脈の内膜にみられる毛細血管のあるものは 内腔と交通しているといわれる。これら新生血 管の意義について, fluid perfusion, 壁内出血, これとよる内腔狭窄，二次的壁在血栓形成求よ び hemosiderin 沈着に関係し, 動脈硬化の進 展に関与するといわれる。島本ら坏による と atheroma に新生して来る毛細血管には basement membrane を有するが，内皮細胞を 欠くものがあり，ここで下流の静脈に収縮がお これば，容易に渗出といら機転が考光られると いら。中島25) も動脈壁の浮腫性膨化 巣の一端 に小血管が存在し，その先端から扇状に拡がる 浮腫状膨化の像を証明し，内膜内新生血管の役 割を想定している。

\section{3. その他の動脈疾患と Vasa vasorum}

脈なし病 Pulseless disease に和いて, 障害 されている血管の外膜にある Vasa vasorum の 内膜の肥厚と内腔の狭窄が見られ，脈なし 病にみられる外膜と中膜の変化がそのVasa

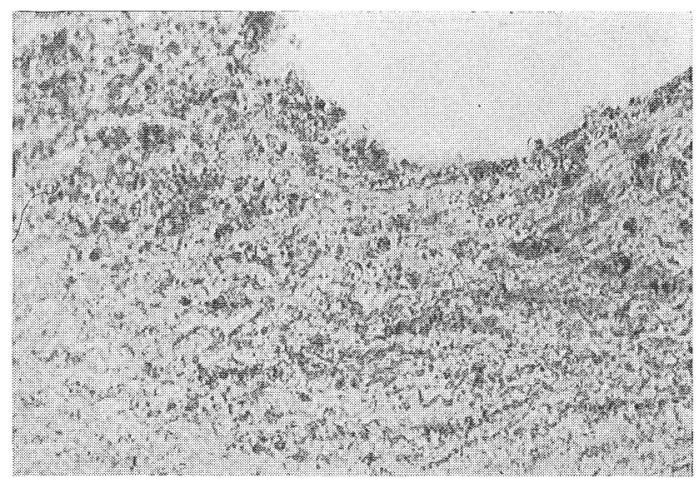

図 9 cholesterol-methylthiouracil 飼育犬の栄盖 血管傷害部位の大動脈の sudan III 染色染本。 $100 \times$ 中膜に赤橙色に染る陽性所見あり。

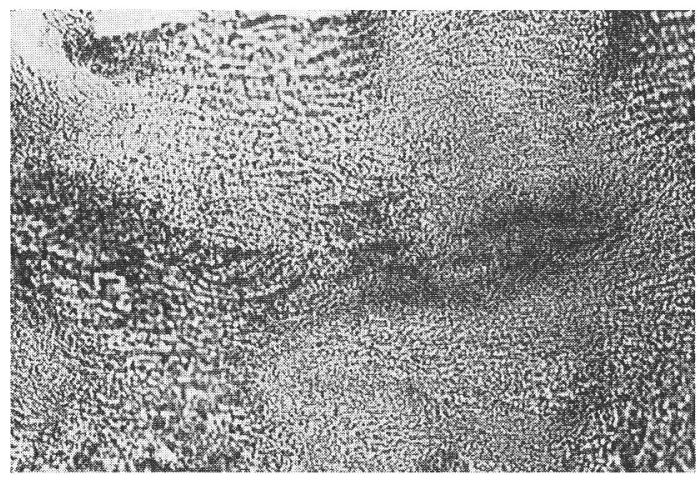

図 10 cholesterol-methylthiouracil 飼育犬の栄 善血管障害部位の大動脈の Liebermann-Schultz 染色 (cholesterol). $100 \times$

中膜に青黑くなたは緑色に染る陽性物質むり。

vasorum の変化に起因寸るとも考它られるが， Vasa vasorum にこのような変化をきたす機転 については知られていない。

その他の閉塞性動脈疾患に扣いてはVasa vasorum 慄血行路として重要な働きをしてい る。川瀬 ${ }^{23)}$ は実験的に作製した家鬼おょび犬 の四肢主幹動脈の閉塞性化膿性血管炎と血管結 紮による閉塞実験，ならびに Buerger 氏病の切 䉼肢について検討し，中膜扣よび外膜に Vasa vasorum が拡張，増加しているのを認め，Vasa vasorum が副血行路の役割を有していると述べ ている。 
冠動派の Vasa vasorum について, Clarke ${ }^{12)}$ は主幹から起始した栄養動派が隣接の冠動挀の 血管壁に分枝していることを認め，これを副血 行枝と呼んでいるが，これは血管閉塞に際し速 やかに側副血行路に転ずるものであろら。

このよらな事が Vasa vasorumに富む冠動 脈では硬塞に際し側副血行が発達しやすく, Vasa vasorum を欠く脳動挀では側副血行を生 じにくい一因になっているのかも知れない。

次に高血圧と Vasa vasorum の関係につい て, Schönenberger ら ${ }^{24)}$ は興味ある実験を行 なっている。すなわち牛の大動脈壁における Vasa vasorum の血流量と血管抵抗の測定から, 血圧が上昇すれば血流量が増加して, 血管抵抗 が減少するが，これは最高血圧 $140 \mathrm{mmHg}$ まで で， $140 \mathrm{mmHg}$ 以上に上昇すれば逆に血流量が 減少すると共に血管抵抗が増すことを確かめ, 高血圧者ではこの面からも, 血管壁の栄養障害 による血管変化を抗こしやすい事が考えられ る。

\section{おわりに}

血管壁に分布する Vasa vasorum の研究は主 として解剖学的研究に止って拈り, Vasa vasorum の血流がいかなる条件で増減するか, これ を調節するものは神経因子のみであるか, kinin のごとき chemical mediator が介在するかにつ いてもほとんど知られていない。Vasa vasorum の各種血管病变の発生, 進展に及ぼす役割につ いては, 剝離性動脈瘤についてかなりの成績が 集まっているが，その他の疾患については断片 的な知識が得られているに過ぎず，今後の検討 に俟つ所が大きい。今回は私共の犬大動脈の Vasa vasorum 傷害実験の成績をもとにして若 干の推論を試みた。
なお glomus tissue と Vasa vasorum の関係， ボタロー氏管閉塞と Vasa vasorum の問題につ き最近の見解を紹介した。

\section{文献}

1) Clarke, J.A. : Ztsch. Zellforsch., 66; 212, 1965.

2) Clarke, J.A.: Anat. Anz., 116; 1, 1965.

3) Clarke, J.A.: J. Anat., 99; 877, 1965.

4) Clarke, J.A.: Acta. Anat., 61; 6, 1965.

5) Clarke, J.A.: Ztsch. Anat. Entwickl., 124; 396, 1965.

6) Clarke, J.A.: J. Anat., 99; 527, 1965.

7) 中村 隆, 㨶田克彦, 大場富雄汪か: 脈管学, 10; 297, 1970.

8）中村 隆, 㨶田克彦, 館野静香注か: 脈管学, 10; 302, 1970.

9）塚本金助：日大医誌， 11；998，1952.

10）中山知雄：解剖学雑誌， 40；9，1965.

11）須永俊明, 佐々木俊明, 島本多喜雄: Jap. Circulat. J., 31；339, 1967.

12) Clarke, J.A.: J. Anat., 98; 539, 1964.

13) Hughes, T.: Nature, 205; 149, 1965.

14) Hughes, T., Angiology, 17; 833, 1966.

15）窪田金次郎：医学のあゆみ， 55； 556， 1965.

16) Harms, D.: Ztschr. Zellforsch., 72; 344, 1966.

17) Schlichter, J.G., and Harris, R.: Am. J. Med. Sci., 218; 610, 1949.

18) Wilens, S.L., Malcolm, J.A., and Vazquez, J.M.: Am. J. Path., 47 ; 695, 1965.

19）仲田幸交：Jap. Circulat. J., 31；275， 1967.

20) Schutte, H.E.: Angiologica, 5; 210, 1968.

21) Adams, C.W.M. \& Bayliss, O.B.: J. Atheroscl. Res., 10; 327, 1969.

22）中島輝之：綜合臨牀， 16；1914，1967.

23）川瀬貞臣：日外会誌， 60；92, 1959.

24) Schönenberger, F. und Müller, A.: Helvet. physiol. et pharmacol. Acta, 18; 136, 1960. 